\title{
Corticotropin-Releasing Factor in Cerebellar Afferent Systems: A Combined Immunohistochemistry and Retrograde Transport Study
}

\author{
Sharon Cummings, ${ }^{1}$ Burt Sharp, ${ }^{2}$ and Robert Elde ${ }^{1}$ \\ Departments of ${ }^{1}$ Cell Biology and Neuroanatomy and ${ }^{2}$ Medicine, The University of Minnesota, Minneapolis, Minnesota \\ 55455
}

The flocculus and paraflocculus of cat and sheep cerebellum were studied with immunohistochemical methods, using antisera to corticotropin-releasing factor (CRF). CRF immunoreactivity was present within 3 populations of varicose nerve fibers. One population of CRF-immunoreactive (CRFIR) fibers appeared to appose Purkinje cell somata and to follow their dendrites into the molecular layer. This arrangement suggested they were climbing fibers. A second group of CRF-IR profiles reminiscent of mossy fibers was widely distributed throughout the granule cell layer. A third population of CRF-IR fibers was present as a beaded plexus lying parallel to the pial surface, above and subadjacent to the Purkinje cell layer. The fibers of this plexus extended into the Purkinje cell layer and surrounded these somata.

The source of some of the CRF-IR fibers within the flocculus and paraflocculus was determined by a retrograde axonal transport study utilizing the fluorescent tracer Fast blue (FB) in combination with the immunohistochemical localization of CRF. It was determined that CRF-IR perikarya within the inferior olivary nucleus gave rise to a population of climbing fibers within those lobules. Furthermore, all divisions of the inferior olive were found to contain CRF-IR somata. This latter finding suggests the potential for CRF. IR climbing fiber projections from the inferior olive to other regions of the cerebellar cortex. The existence of CRF-IR mossy fibers and fibers within the ganglionic plexus suggests the possibility of CRF-IR afferent projections from other regions of the brain stem to the flocculus and paraflocculus.

The 41 amino acid peptide, corticotropin-releasing factor (CRF), sequenced and synthesized by Vale and colleagues in 1981 (Spiess et al., 1981; Vale et al., 1981), was localized immunohistochemically in the hypothalamus soon after its discovery (Bloom et al., 1982; Paull et al., 1982; Cummings et al., 1983; Swanson et al., 1983). However, it became apparent that CRF, similar

\footnotetext{
Received Jan. 20, 1987; revised June 29, 1987; accepted July 21, 1987.

This work was supported in part by a doctoral dissertation fellowship from the Graduate School of the The University of Minnesota (S.C.). We wish to thank Dr. Kenneth E. Miller for helpful advice, Dr. Virginia Seybold for critical reading of the manuscript, and Dr. Georgia Bishop for assistance in interpretation of data from the cat inferior olive.

Correspondence should be addressed to Sharon Cummings, Ph.D., Department of Anatomy and Neuroscience Program, The Ohio State University, 4072 Graves Hall, 333 W. 10th Ave., Columbus, OH 43210.

Copyright (C) 1988 Society for Neuroscience $0270-6474 / 88 / 020543-12 \$ 02.00 / 0$
}

to other hypophysiotropic hormones such as leuteinizing hormone-releasing hormone (Witkin et al., 1982), thyrotropin-releasing hormone (Johansson and Hökfelt, 1980), growth hormone-releasing factor (Sawchenko et al., 1985), and somatostatin (Johansson et al., 1984), was present not only within hypophysiotropic neurons, but also occurred in widely distributed neuronal systems (Fischman and Moldow, 1982; Olschowka et al., 1982; Cote et al., 1983; Cummings et al., 1983; Schipper et al., 1983; Swanson et al., 1983; Merchenthaler, 1984).

In previous studies we reported the presence of CRF-immunoreactive (CRF-IR) fibers in rat cerebellar cortex (Cummings et al., 1983) and in the flocculus and paraflocculus of cat and monkey cerebellum (Cummings et al., 1985). However, reports conflict on the existence of CRF immunoreactivity within the cerebellum. Other immunohistochemical studies have reported CRF fibers in rat cerebellum (Olschowka et al., 1982; Merchenthaler, 1984), and in the anterior vermis of human cerebellum (Powers et al., 1986), but some have been unable to verify this (Swanson et al., 1983). Varying levels of CRF immunoreactivity in the cerebellum have been reported in radioimmunoassay studies (Fischman and Moldow, 1982; Cote et al., 1983), but other investigations have been unable to detect the CRF immunoreactivity in that region by radioimmunoassay (Palkovits et al., 1985). A radioimmunoassay study utilizing 4 antisera directed against either the rat or ovine sequences detected CRF-IR in cerebellar extracts only with the ovine antisera (Skofitsch and Jacobowitz, 1985). Recently, however, specific binding sites for ${ }^{125} \mathrm{I}-\mathrm{Tyr}-\mathrm{oCRF}$ (Wynn et al., 1984) and for $\mathrm{Nle}^{21},{ }^{125} \mathrm{I}_{-} \mathrm{Tyr}^{32}$-oCRF (De Souza et al., 1986), were identified within the cerebellar cortex. In the latter study, the specific binding of the radiolabeled CRF receptor ligand was reported to be higher in the cerebellum than in several other areas of the rat CNS. The existence of CRF binding sites in the cerebellum strongly suggests a functional role for a CRF-like peptide within that region.

The present study was undertaken to clarify discrepancies on the existence of CRF within the cerebellum. We had observed consistent populations of CRF-IR fibers in the flocculus and paraflocculus, and therefore restricted this study to those regions. Hypothesizing that CRF-IR fiber populations within those lobules might arise from extrinsic sources, a retrograde tracing study was undertaken, in combination with immunohistochemical localization of CRF, in order to ascertain possible sources. The focus of this initial double-label study was directed primarily to the inferior olive, the only known source of cerebellar climbing fibers. 


\section{Materials and Methods}

Localization of CRF in flocculus and paraflocculus. Cats (body weight $1-2 \mathrm{~kg} ; n=5)$ and lambs $(n=2)$ were included in this study. The animals were obtained from the Research Animal Resources Division of the University of Minnesota or from other ongoing investigations. All animals were anesthetized with sodium pentobarbital and perfused transcardially with saline followed by a fixative of picric acid/phosphate $(0.1 \mathrm{M})$ buffered $2 \%$ paraformaldehyde ( $\mathrm{pH} 7.3)$ (Stephanini et al., 1967) at room temperature. The brains were removed, immersed in the same fixative for $90 \mathrm{~min}$ and stored overnight in $5 \%$ sucrose in $0.1 \mathrm{M}$ Sorenson's phosphate buffer, $\mathrm{pH} 7.3$ The flocculus and paraflocculus were dissected free from the cerebellum. The tissues were treated by 1 of 2 procedures: (1) the individual lobules were sectioned at 50 or $75 \mu \mathrm{m}$ on a sliding microtome and processed by the peroxidase-antiperoxidase (PAP) method of Sternberger (1979) modified for free-floating sections as previously described (Cummings et al., 1983), or (2) the lobules were embedded together within a single block of brain paste in an orientation to permit sectioning of the lobules in the transverse or sagittal plane, and $10 \mu \mathrm{m}$ sections of the frozen tissue block were cut in a cryostat. Slide mounted sections were hydrated with PBS and processed for the indirect immunofluorescence technique of Coons (1958) as modified and previously described for CRF (Onstott and Elde, 1984). Sections were counterstained with ethidium bromide, a fluorescent Nissl stain (Schmued et al., 1982), in order to define Purkinje cell and granule cell somata. Sections were mounted in a fade-retarding medium (Platt and Michael, 1983), examined and photographed using a Zeiss standard fluorescence microscope fitted with epi-illumination. Fluorescein-isothiocyanate and ethidium bromide staining were visualized using appropriate filter combinations (FITC: excitation $450-490 \mathrm{~nm} / \mathrm{emission}$ $520-560 \mathrm{~nm}$; ethidium bromide: excitation $546 \mathrm{~nm}$ [bandpass]/emission $590-\infty \mathrm{nm}$ ).

Double-labeling histochemistry. A tract-tracing study, using the retrogradely transported fluorescent dye Fast blue (FB), was undertaken in order to determine the origin of the CRF-containing fibers within the floccular and parafloccular cortex. Randomly bred cats (1-2 kg; $n=$ 5) were treated with atropine sulfate $(0.1 \mathrm{mg} / \mathrm{kg}$ body weight, s.c.) and $10 \mathrm{~min}$ later anesthetized with sodium pentobarbital $(38 \mathrm{mg} / \mathrm{kg}$ body weight, i.p.). The animals were secured in a stereotaxic frame and the right lateral cerebellum was exposed via a dorsal craniotomy. Using a Hamilton syringe connected to a 27 gauge needle with PE-20 tubing, multifocal pressure injections (up to $10 \mu$ l total injection) of a suspension of FB ( $1 \%$ in distilled $\mathrm{H}_{2} \mathrm{O}$; Dr. Illing, K. G. Makromolekulare Chemie, Grob-Umstadt FRG) were delivered to the flocculus and dorsal and ventral paraflocculus over a period of $30 \mathrm{~min}$. Following the injections, the wound was covered with Gel-Foam (Upjohn) and closed. Five days later the animals were reanesthetized and colchicine $(300 \mu \mathrm{g}, 1 \mathrm{mg} / \mathrm{ml})$ was administered by pressure injection to the fourth ventricle in order to provide enhancement of CRF immunoreactivity in perikarya of the brain stem. Penicillin (Flo-cillin, Bristol; 300,000 U/d, s.c.) was administered from day 1 of the experiment. Forty-eight hours after colchicine administration, the animals were reanesthetized and perfused intracardially with 1 liter of $0.9 \%$ saline followed by 2 liters of picric acid/phosphate buffered $2 \%$ paraformaldehyde fixative (pH 7.3) (Stephanini et al., 1967). The brain was removed and immersed in the same fixative for $90 \mathrm{~min}$ and stored overnight in $5 \%$ sucrose in $0.1 \mathrm{M}$ Sorenson's phosphate buffer, pH 7.3. The brain stem was frozen and sectioned at $50 \mu \mathrm{m}$ on a sliding microtome in the coronal plane. Sections were wet-mounted onto glass slides and FB-containing areas were photographed without coverslips with a Zeiss standard fluorescence microscope (transmitted UV illumination; UGl excitation filter [bandpass $300-400 \mathrm{~nm}$ ], barrier filter $410 \mathrm{~nm}$, long pass). The sections were then removed from the slides, incubated overnight with antiserum to rat CRF (1:2000), and processed by the PAP procedure previously described (Cummings et al., 1983). These sections were then rinsed, wetmounted onto gelatin-coated slides and rephotographed without coverslips with an Olympus bright-field microscope. The sections were then allowed to dry overnight at $40^{\circ} \mathrm{C}$, dehydrated in an ascending series of ethanol, and coverslipped with Entellan.

Photographs and negatives of tissue sections containing cells labeled by both retrograde transport of $\mathrm{FB}$ and peroxidase immunoreactivity for CRF were compared for colocalization of both substances.

Localization of CRF in the inferior olive. Each $50 \mu \mathrm{m}$ section of cat brain stem analyzed in the double-labeling study described above was further examined and mapped for distribution of CRF-IR cells within the inferior olivary complex. The inferior olivary projection to the cer- ebellum is wholly crossed. Therefore, the fluorescent dye was transported only to the left side. The inferior olivary nuclei on both sides of the brain stem were observed and compared with bright-field microscopy in order to determine that the pattern of staining for CRF immunoreactivity was identical and that the appearance or specificity of immunostaining on the left side, to which there was FB transport, was not altered by the presence of the fluorescent dye.

Characterization of antisera. The lamb tissue was incubated overnight in ovine CRF primary antiserum (1/500) (ImmunoNuclear Corp., Stillwater, MN) characterized and described previously (Cummings et al., 1983). The cat tissue was incubated in a primary antiserum (1/5000) directed against rat/human CRF produced in rabbits with a synthetic rat CRF-keyhole limpet hemocyanin conjugate. Controls for the specificity of immunohistochemical localizations of this rat CRF antiserum were performed by incubating sections with antiserum that had been pretreated overnight at $4^{\circ} \mathrm{C}$ with an excess of synthetic rat CRF $(10 \mu \mathrm{g})$ $\mathrm{ml}$ of diluted (CRF antiserum). All of the staining observed was found to represent immunohistochemically specific localizations because no staining was found in structures on sections that served as absorption controls. Furthermore, the PAP procedure was conducted on filter paper (Whatman No. 1) upon which various synthetic peptides had been immobilized with vapor-phase paraformaldehyde fixation according to the method of Larsson (1981). The peptides tested included ovine CRF, rat CRF, Lys ${ }^{8}$-vasopressin, Arg $^{8}$-vasopressin, oxytocin, dynorphin ${ }_{(1-17)}$, Met-enkephalin, and Leu-enkephalin. Each peptide was tested at quantities varying from $10 \mathrm{nmol}$ to $10 \mathrm{pmol} / \mathrm{blot}$. The antiserum to rat CRF stained blots containing as little as $10 \mathrm{pmol}$ of rat or ovine CRF. In contrast, this antiserum did not stain blots containing $10 \mathrm{nmol}$ of the other peptides listed above. Thus, cross-reactivity with these other peptides, if it exists, is less than $0.1 \%$.

\section{Results}

In this study we have (1) demonstrated the existence of 3 morphologically distinct populations of CRF-IR fibers in the flocculus and paraflocculus of cat and sheep cerebellum, (2) determined the distribution of CRF-IR cell bodies within the inferior olive of the cat brain stem, and (3) demonstrated a projection of CRF-IR fibers to the flocculus and paraflocculus of the cat from cell bodies within the inferior olive.

\section{Distribution of CRF-IR fibers in the flocculus and paraflocculus}

One population of CRF-IR fibers within the flocculus and paraflocculus extended into the Purkinje cell layer from the granule cell layer, surrounded the Purkinje cells, and appeared to follow their dendrites into the molecular layer toward the pial surface (Figs. 1, $A, B ; 2, A, B$ ). This system of fibers gave rise to varicosities that appeared to be intimately associated with Purkinje cell somata. Throughout their course along the Purkinje cell dendrites, these fibers emitted short, beaded collaterals that extended laterally or appeared to parallel the parent fiber. This population was similar in appearance to climbing fibers, as have been described in Golgi preparations (Ramon y Cajal, 1911; Palay and Chan-Palay, 1974). These CRF-containing climbing fiber-like profiles were not uniformly distributed throughout the cortex of either flocculus or paraflocculus. The density and staining intensity of CRF-IR climbing fibers was greater in the flocculus than in the paraflocculus. CRF-containing climbing fibers appeared least dense and more delicately immunoreactive in the dorsal paraflocculus. As the distribution patterns were consistent from section to section in single animals, as well as between animals, this variation did not appear attributable to staining artifact.

A second type of CRF-IR fibers was present throughout the granule cell layer of both the flocculus and paraflocculus. At the light microscopic level, this complex appeared to consist of 2 types of profiles. Beaded fibers of fine diameter were present 

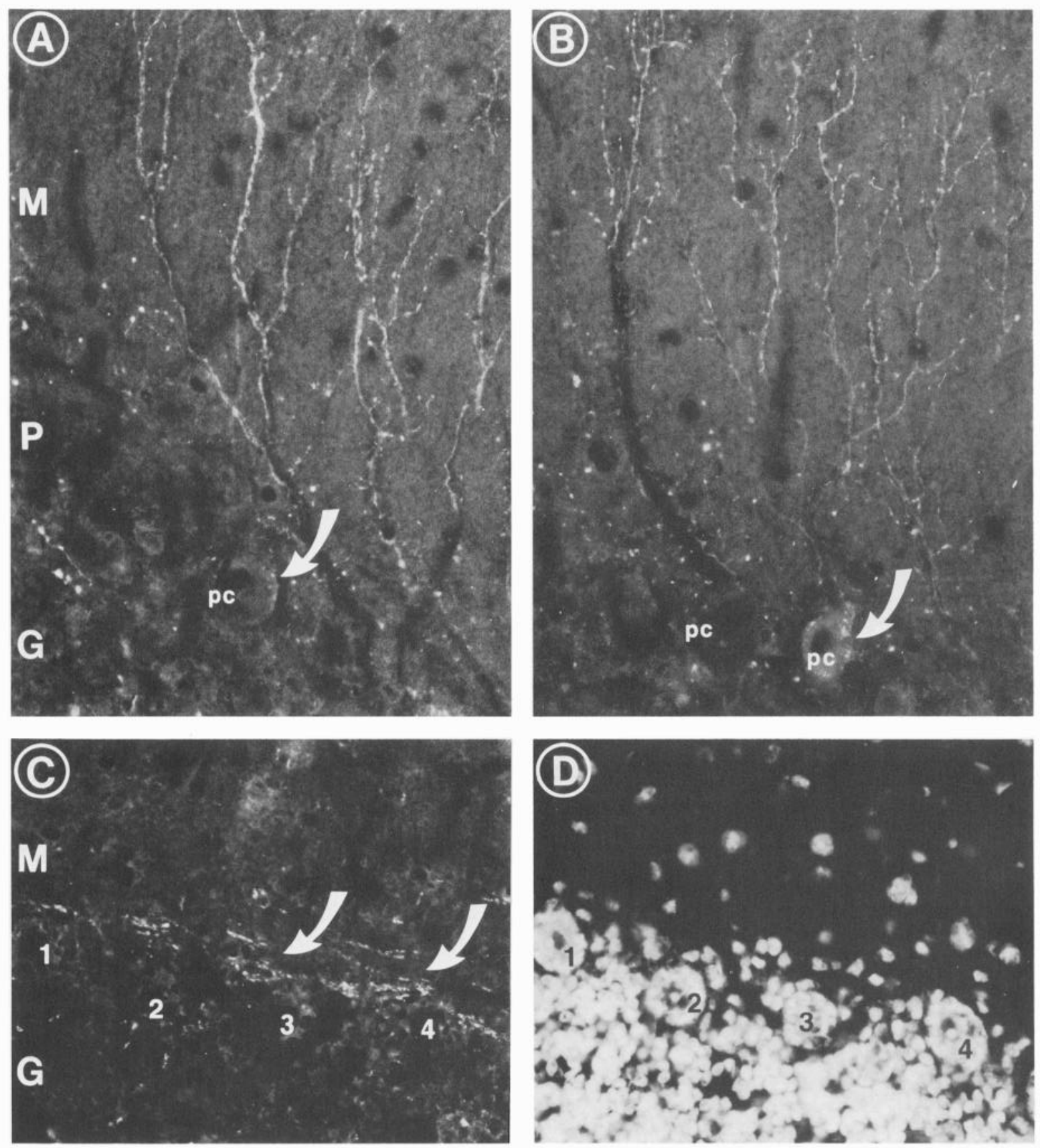

Figure 1. Immunofluorescence $(A-C)$ and fluorescence $(D)$ photomicrographs of $10 \mu \mathrm{m}$ sagittal sections of cat paraflocculus after incubation with antiserum to rat/human CRF. CRF-immunofluorescent fibers are present within the molecular, Purkinje cell, and granular layers. $M$, molecular layer; $P$, Purkinje cell layer; $p c$, Purkinje cell; $G$, granule cell layer. $A$ and $B$, CRF-IR climbing fiber-like profiles associated with Purkinje cell bodies appear to follow dendrites into the molecular layer, where they give rise to fine, beaded collaterals and terminal arborizations. Curved arrows indicate CRF-IR varicosities adjacent to Purkinje cell somata. $\times 290$. $C$ and $D$, In $C$, the same section photographed in $D$ is viewed with appropriate filters to visualize fluorescein-isothiocyanate immunostaining $(C)$ and the fluorescent Nissl counterstain ethidium bromide $(D)$. $C$, CRF-IR beaded fiber plexus is present at the level of the Purkinje cell layer. Fibers visible within this section lie superior to the Purkinje cells. Curved arrows indicate CRF-IR varicosities adjacent to Purkinje cell somata. Numbers indicate corresponding Purkinje cells in each photograph. $\times 290$.

which frequently displayed expanded varicosities (Figs. 2, $A-C$; $3, A, B, D, E)$. Other profiles appeared as enlarged, irregular globules or coarse rosette-type configurations of variable size and extent (Figs. 2C; 3, D, E). Overall, the granular layer complex resembled mossy fibers, as have been described in Golgi preparations (Ramon y Cajal, 1911; Brodal and Drablos, 1963; Palay and Chan-Palay, 1974). The mossy fiber-like structures appeared to be components of a population distinct from the
CRF-IR climbing fiber population. Some of these fibers were seen to enter the granule cell layer from the white matter within the medullary center of individual folia (Fig. $3 A$ ) but never appeared to enter the molecular layer. Additionally, populations of mossy fibers and climbing fibers were not always present in parallel (Fig. 3, $A-C$ ). In similarity to the climbing fibers, the mossy fiber-like population was not ubiquitous. The mossy fibers were heavily distributed throughout some individual folia 


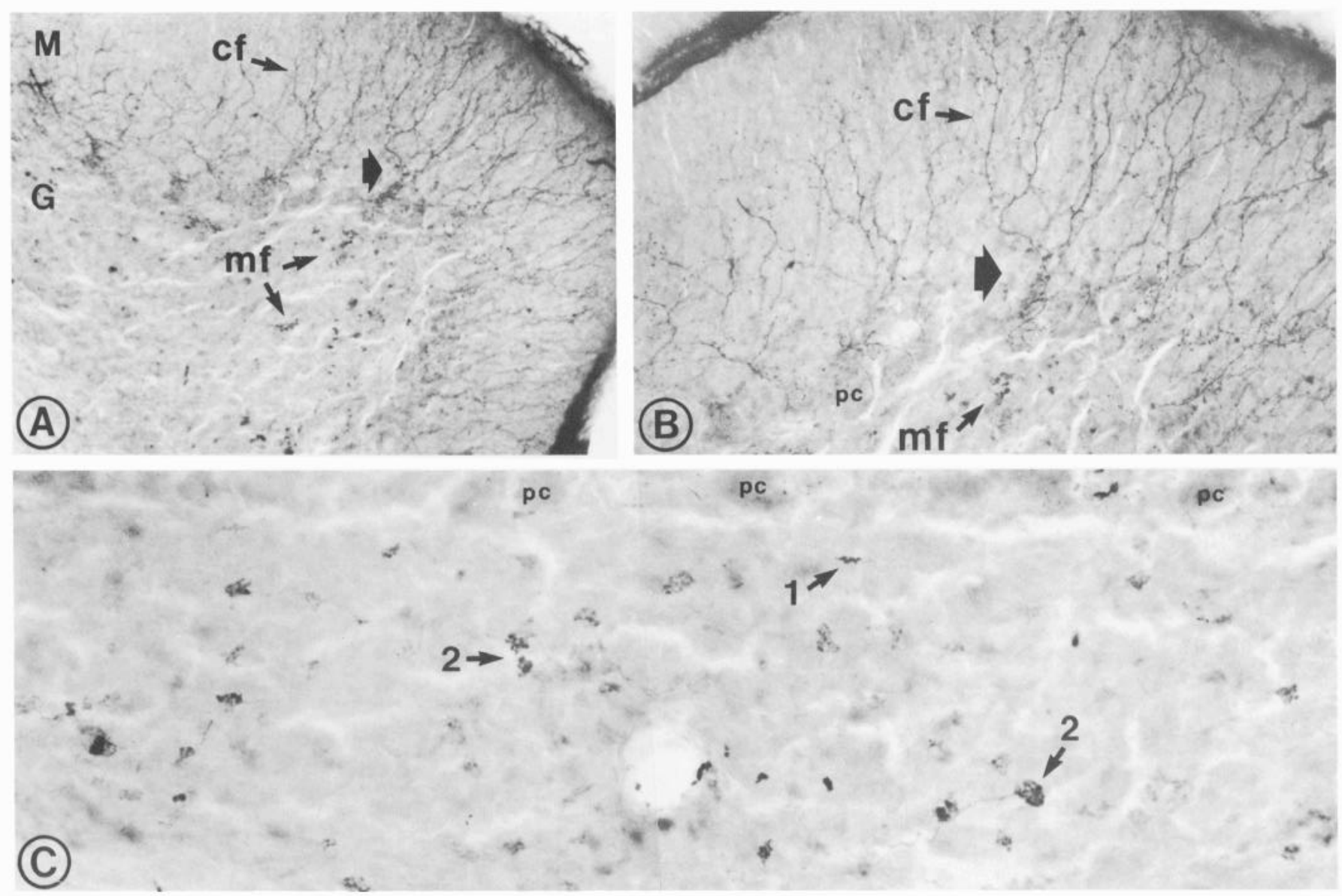

Figure 2. Photomicrographs of PAP labeled $60 \mu \mathrm{m}$ sections of cat flocculus after incubation with antiserum to rat/human CRF. $M$, molecular layer; $G$, granule cell layer; $p c$, Purkinje cell; $c f$, climbing fibers; $m f$, mossy fibers. $A$, Low-power magnification of a single folium of the flocculus to indicate the concomitant appearance of CRF-containing climbing and mossy fibers within this region. Broad arrow indicates area shown at higher magnification in $B . \times 130 . B$, High-power magnification of a portion of the folium in $A$. Broad arrow indicates the same area as indicated in $A$. Climbing fiber parent axons can be seen passing through the Purkinje cell layer and arborizing into terminal branches, giving rise to numerous beaded collaterals. $\times 200$. $C$, Photomontage to illustrate CRF-IR simple (1) and complex (2) mossy fiber rosettes within the granule cell layer of the flocculus. $\times 330$.

and sparsely represented in others. In the flocculus, the mossy fibers were present in greater numbers and were more intensely immunoreactive than in the paraflocculus. As with the climbing fibers, this difference in fiber density and staining intensity was consistent among animals and from section to section within single animals and was not attributable to artifacts of fixation or immunohistochemical processing.

A third complex of finely beaded CRF-IR fibers, present in both cat and sheep, was distributed at the level of the Purkinje cell layer, immediately superficial and/or deep to the Purkinje cell neurons (Figs. $1 C ; 3, A, B, D, E$ ). This system coursed parallel to the pial surface, within the plane of the Purkinje cell layer (Fig. 1C). Fibers and terminals of this complex extended into the Purkinje cell layer and in many instances appeared to surround the Purkinje cell somata (Figs. $1 C, 3 E$ ). Within the lobules studied, this beaded fiber plexus appeared to be broadly distributed, although areas of tissue existed in which elements of this complex were not visible. The location and morphological appearance of this population, when present, was similar to that of the supra- and infraganglionic plexuses described by Ramon y Cajal (1911) and Jakob (1928) (see also Larsell and Jansen, 1972).

Finally, medullary regions of the cerebellum associated with the flocculus and paraflocculus always contained CRF-IR fibers. Finely and coarsely beaded CRF-IR fibers were present throughout medullary regions. At times, fibers were seen to course into the white matter of individual folia.

\section{Distribution of CRF-IR cell bodies in the inferior olive}

Serial sections through the brain stem of cats treated with colchicine revealed the presence of CRF-IR cells in all divisions of the inferior olivary complex (Fig. 4). The density of CRFcontaining somata, as well as the staining intensity of CRF immunoreactivity within the cells varied, however, within di-

Figure 3. Photomicrographs of PAP-labeled $50 \mu \mathrm{m}$ sections of sheep $(A, B, D, E)$ and cat $(C)$ cerebellar cortex after incubation with antiserum to ovine $\operatorname{CRF}(A, B, D, E)$ and rat/human $\operatorname{CRF}(C) . M$, molecular layer; $P$, Purkinje cell layer; $G$, granule cell layer; $W$, white matter; $p c$, Purkinje cell; $c f$, climbing fibers; $m f$, mossy fibers; $f p$, fiber plexus. $A$ and $B$, Apex $(A)$ and base $(B)$ of 2 different folia. Varicose CRF-IR fibers course from central white matter into the core of the folia to emerge along the sides and apex as sprays of mossy fiber-like profiles within the granule cell layer. 

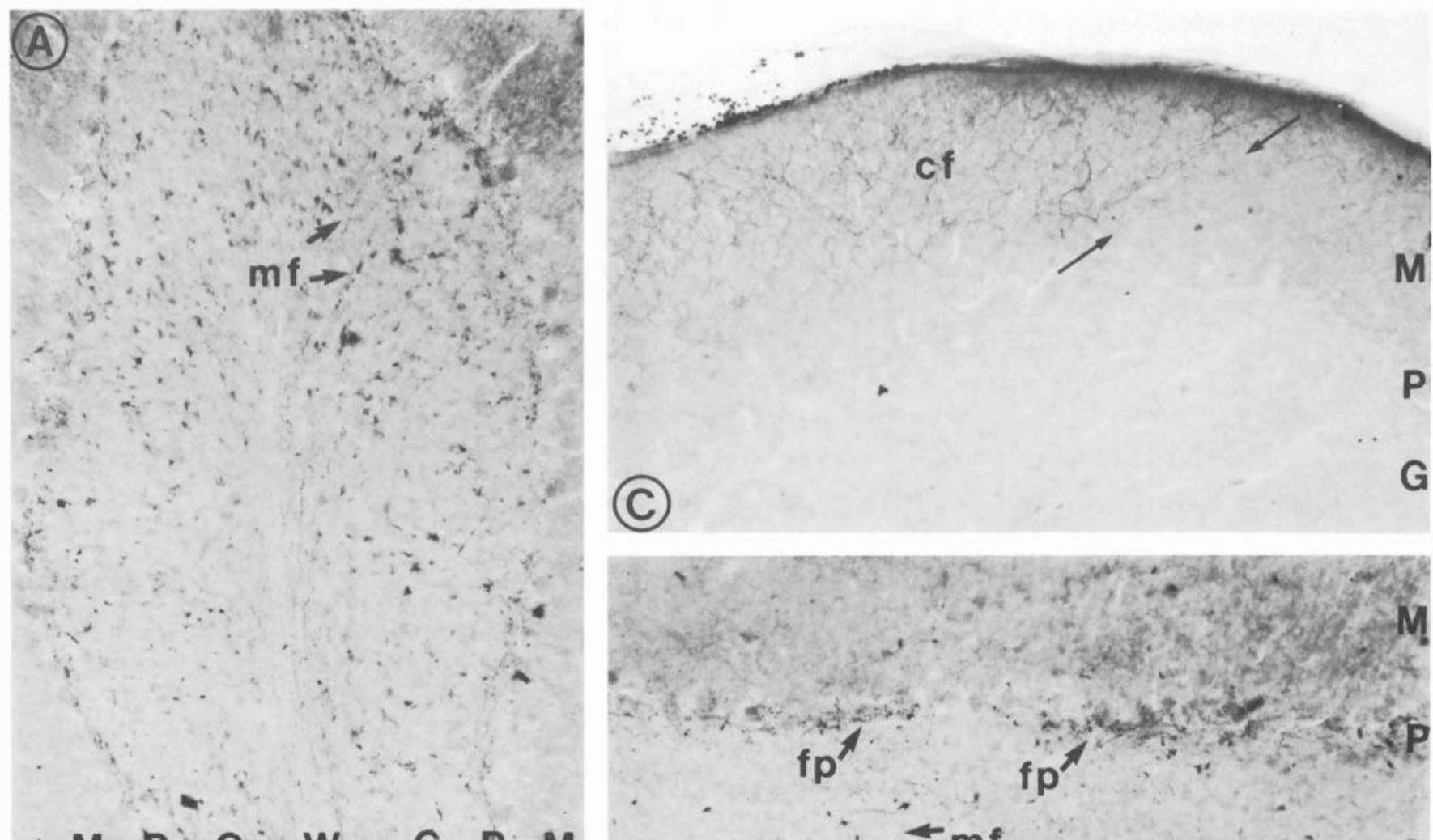

$M P G \quad W \quad G P M$
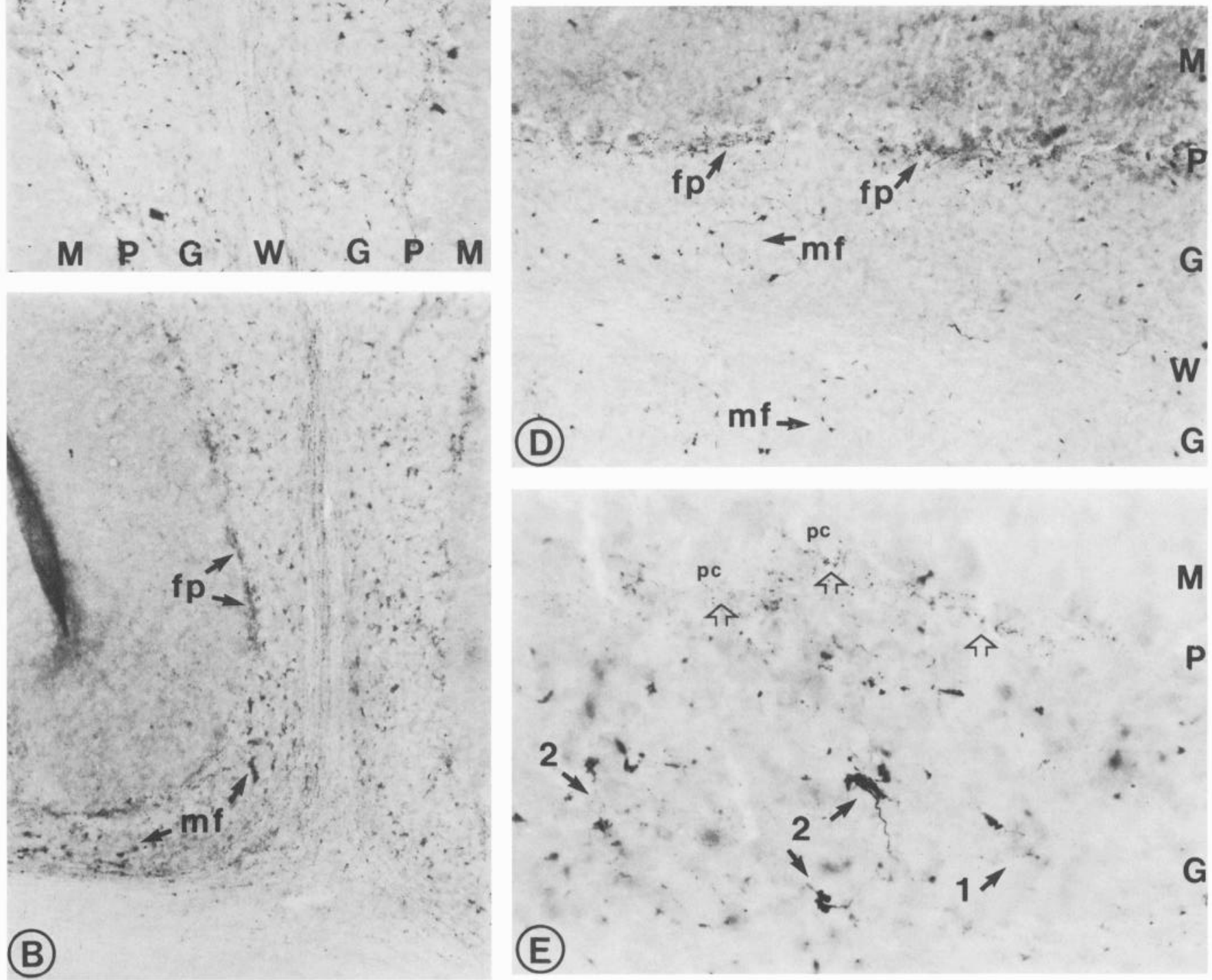

A finely beaded CRF-IR fiber plexus is present at the level of the Purkinje cell layer. $\times 115$. $C$, CRF-IR climbing fibers have a nonuniform, patchlike distribution in the molecular layer of the flocculus. Arrows indicate border of patch. $\times 115 . D$, Photomicrograph of longitudinal section of a folium to illustrate the occurrence of CRF-IR mossy fiber-like profiles within the granule cell layer, and the CRF-IR beaded fiber plexus at the level of the Purkinje cells. $\times 115$. E, Highly magnified photomicrograph of CRF-IR fibers within the Purkinje cell layer and the granule cell layer. The CRF-IR beaded fiber plexus is present at the level of the Purkinje cells. Open arrows indicate CRF-containing varicosites of this system in close apposition to Purkinje cell somata. Fine varicose fibers $(1)$ are present throughout the granule cell layer. Mossy fiber terminal configurations occur as (2) simple enlargements, irregular swellings, or coarsely complicated profiles. $\times 230$. 

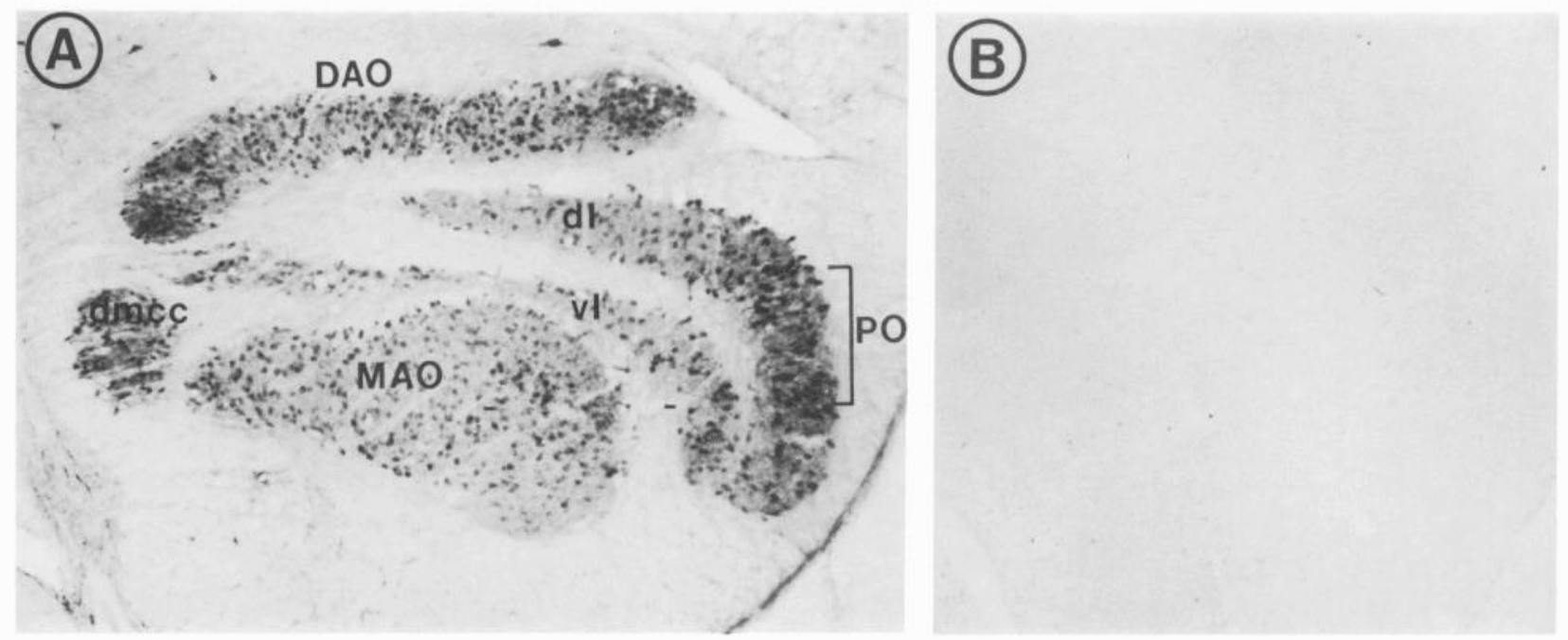

Figure 4. Photomicrograph of 2 closely adjacent $50 \mu \mathrm{m}$ transverse sections of the inferior olivary nucleus of a colchicine-treated cat. A, Section incubated with antiserum to rat/human CRF contains PAP-labeled cell bodies in the dorsal accessory olive $(D A O)$; the dorsal lamella $(d l)$, ventral lamella $(v l)$, and bend region of the principal olive $(P O)$; medial accessory olive $(M A O)$; and dorsomedial cell column $(d m c c)$. B, Section incubated with rat CRF antiserum absorbed with rat CRF shows no CRF-IR cells or fibers. $\times 36$.

visions of the complex. CRF-IR cell bodies were present throughout the rostral-caudal extent of the medial accessory olive (MAO), but were most prominent at the caudal pole and at the most rostral medial tip of that nucleus. A band that was essentially devoid of immunoreactivity appeared to divide caudal MAO into medial and lateral regions. At midolive, when both dorsal and ventral lamellae of the principal olive were present, CRF-IR somata were found primarily in the lateral two-thirds of MAO. Rostrally, at the level where the dorsomedial cell column is well formed, CRF-IR somata were usually prominent only in the lateral one-third of MAO. However, in one heavily colchicine-treated animal, CRF-IR somata appeared to be more widespread even rostrally in MAO. Many strongly immunoreactive CRF-containing somata were always present in nucleus $\beta$ and the dorsomedial cell column. A few scattered lightly stained CRF-IR cell bodies were present in the dorsal cap and caudal ventrolateral outgrowth

The most intensely CRF-IR somata were consistently found in the caudal and lateral regions of the dorsal accessory olive (DAO). In similarity to the MAO, CRF-containing perikarya were present throughout the rostral-caudal extent of DAO but appeared in greater numbers caudally. Rostral to midolive, intensely immunostained cell bodies were consistently present laterally in DAO, but usually fewer and only lightly immunoreactive cells were present medially.

The dorsal and ventral lamellae as well as the bend region of the principal olive always contained numerous CRF-IR cell bodies. There was little CRF immunoreactivity rostromedially in the region of fusion of the dorsal accessory olive with the principal olive.

In summary, all divisions of the inferior olivary complex contained CRF-IR somata. The CRF labeling in the medial accessory and dorsal accessory olive was most widespread at the caudal pole of each of those nuclei and tended to shift laterally toward the rostral poles. The density and staining intensity of CRF-labeled cells were consistently high within the lateral regions of the principal olive.

\section{Origin of CRF-IR afferents to the flocculus and paraflocculus}

After injection of FB to the right flocculus and paraflocculus of cats and a 1 week survival interval, retrogradely labeled cell bodies were found within the contralateral MAO, dorsal and ventral lamellae, and lateral bend region of the principal olive and the dorsal cap (Figs. $5, B, D ; 6, B, D$ ). Subsequent processing of the FB-labeled sections for CRF immunoreactivity revealed that the majority of retrogradely labeled neurons in the inferior olive also stained positively for CRF (Figs. 5, $A, C ; 6, A, C$ ). A number of retrogradely labeled cells were also present in each section of the inferior olive which were not immunoreactive for CRF; additionally, CRF-IR somata were visible throughout the complex which were not retrogradely labeled with FB.

FB injections to the flocculus and paraflocculus also labeled cells in regions of the brain stem other than the inferior olive. These regions included the medial vestibular nucleus, the perihypoglossal complex, medullary and pontine reticular formations, and raphe nuclei. After processing for the PAP procedure, CRF-IR somata were also present in these regions. However, critical analysis of the FB/CRF-cocontainment within these extraolivary regions will be presented in a subsequent paper.

\section{Discussion}

\section{Distribution of CRF immunoreactivity within the flocculus and paraflocculus}

We have previously reported the localization of CRF-IR fibers within the molecular layer of rat cerebellar cortex using an antiserum to ovine CRF (Cummings et al., 1983) and in cat and monkey cerebellum using an antiserum to rat/human CRF (Cummings et al., 1985). We have now identified 3 morphologically discrete systems of CRF-containing fibers within the flocculus and paraflocculus of cat and sheep with rat/human and ovine CRF antiserum. CRF-IR profiles were present in populations resembling climbing fibers and mossy fibers and in a plexus of beaded fibers that extended between and surrounded Purkinje cell somata. CRF-IR labeling appeared to be specific, 

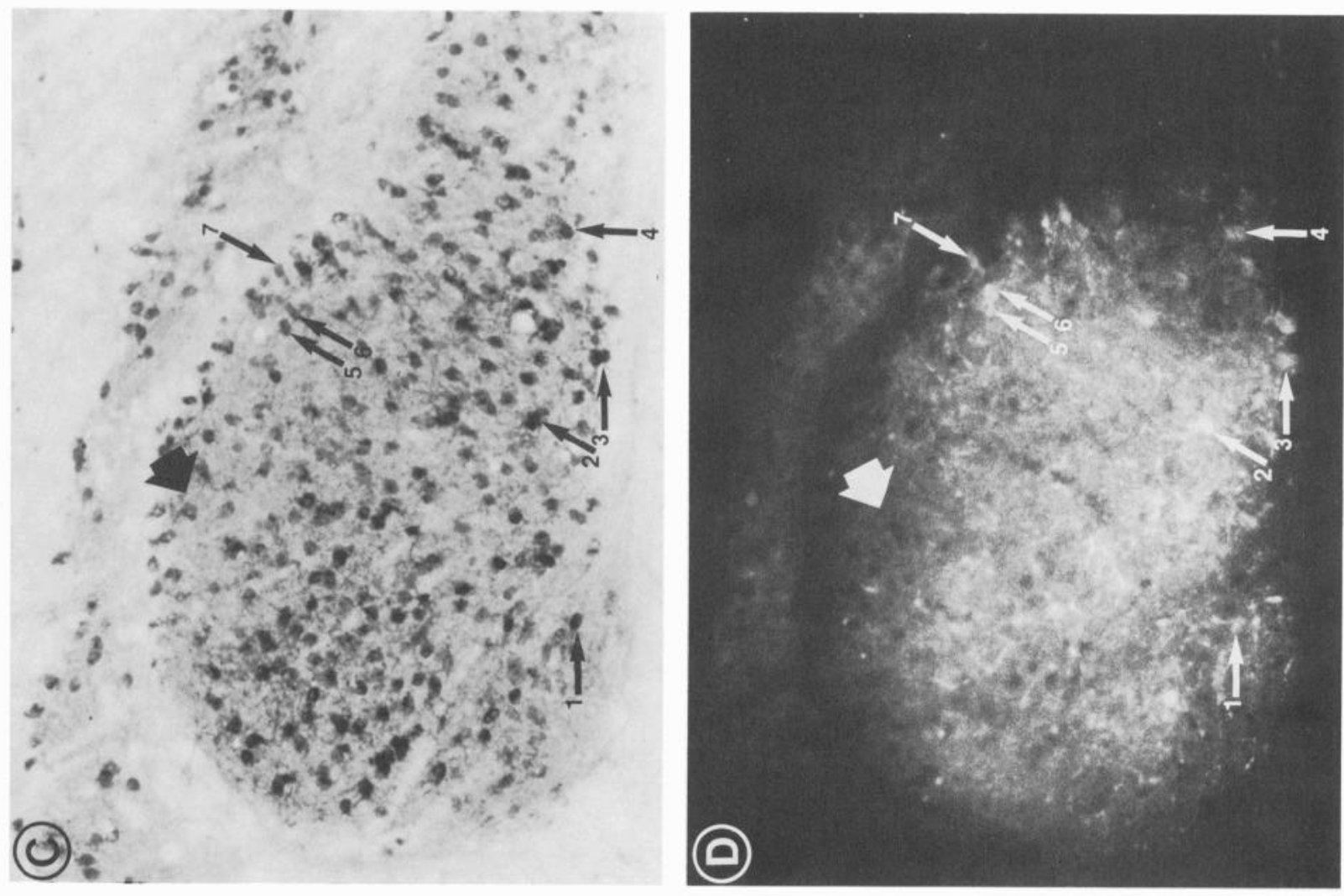

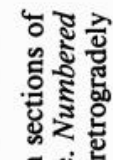

灵写究

ธัँ

$\checkmark 8$.

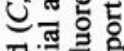

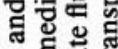

कิ ह 든

ن농

응

记월

N

멸

年

동

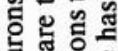

硛

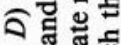

बण.

ن. 3

8 느의

읭

焉欲

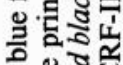
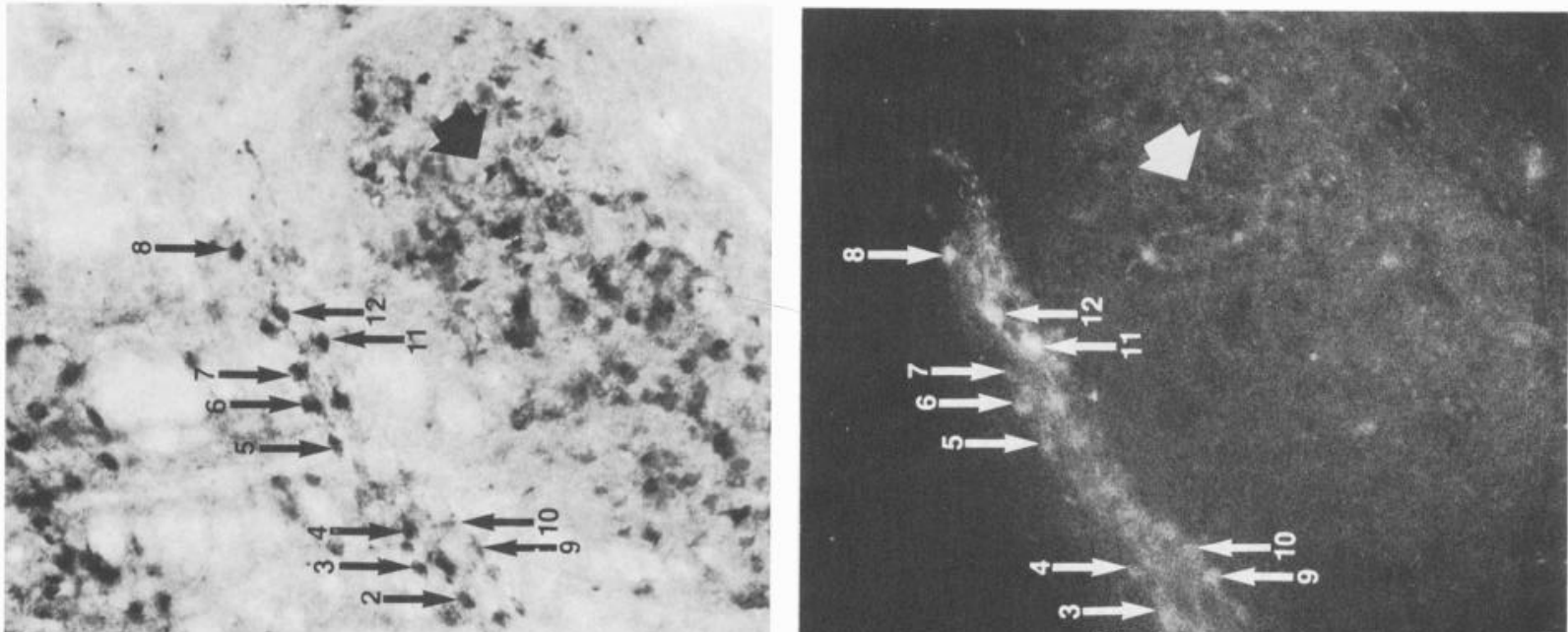

政

政论

콜

$\sigma$ 탰

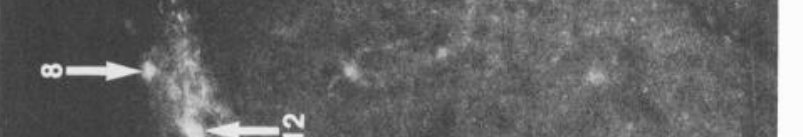

S可.

ठ틍

政:

政

믈

읨․

政

용

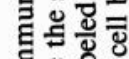

통

1

엄을

낭 뒁

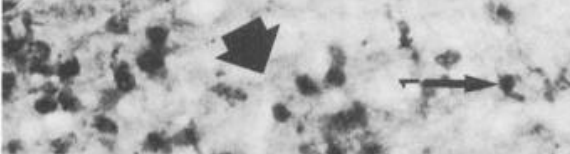

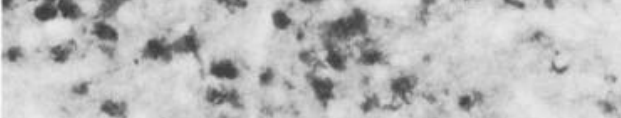

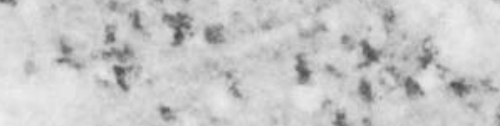

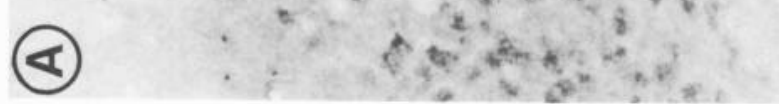



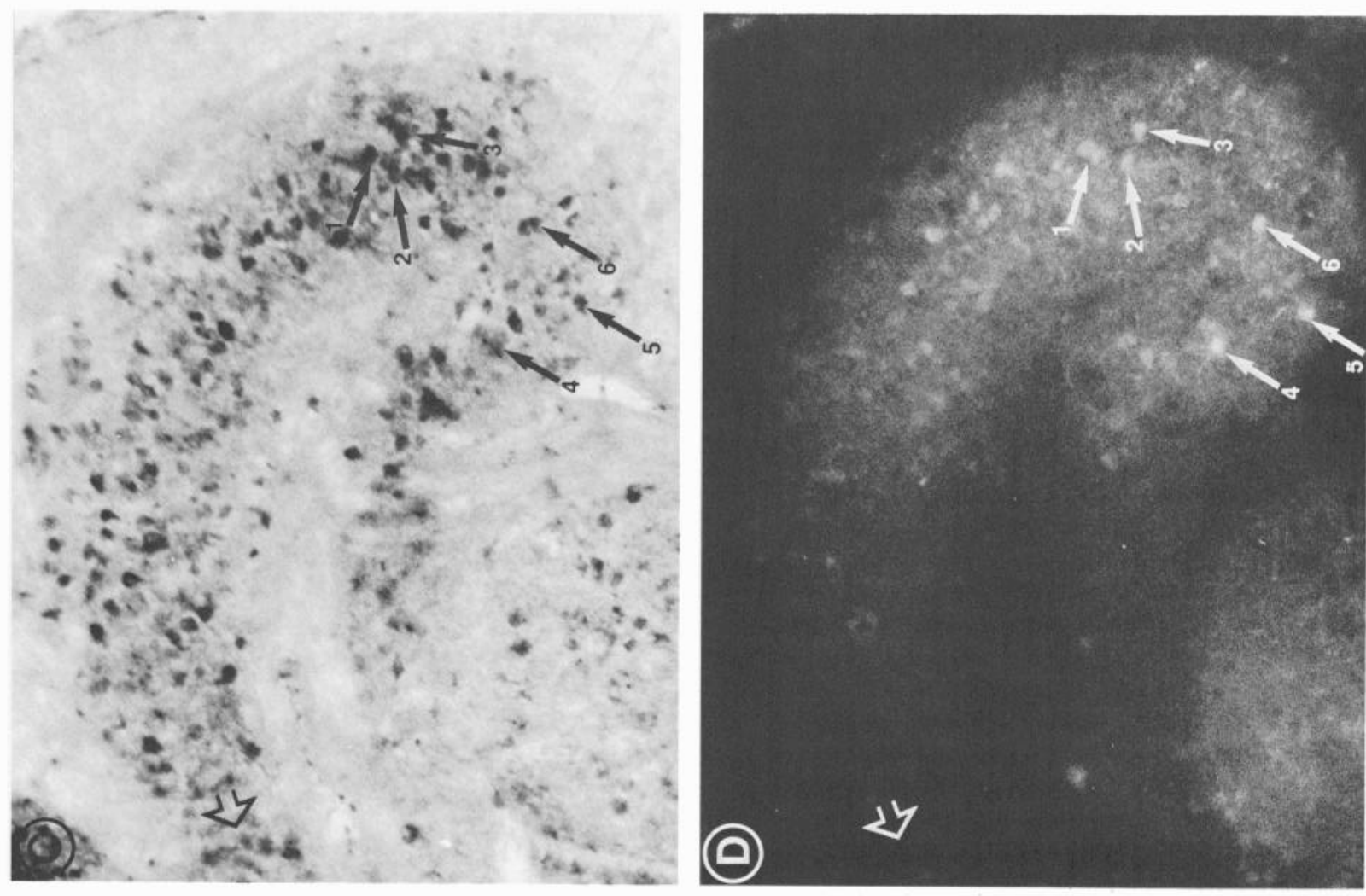

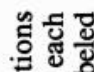

递. 주

寻卷密

유류

응

ล。

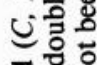

דo

同들

Si:

遍

N

最富

등워

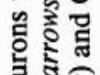

总范

ลิธั้

๑ इ

सं क्ष

\&

苍总

g

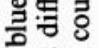
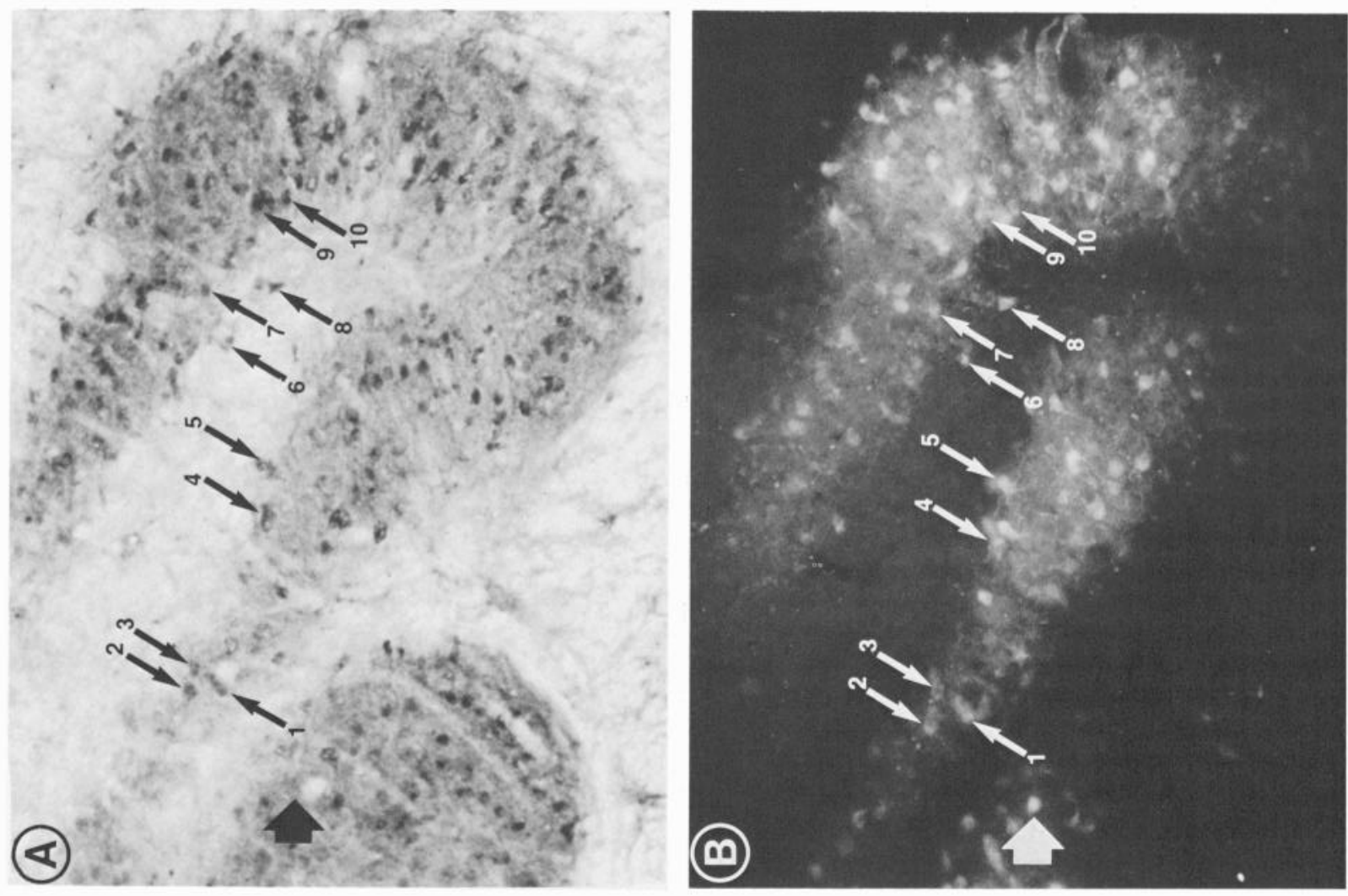

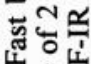

僖

등

0 증

S동

政

氙

में

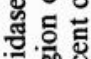

인

뭉을

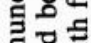

룽

造

픙

늘 웡

응

跣

品?

운을

ํㅜㄹ

홍 웜댕.

을

-

ธิํํ원 
in an immunohistochemical sense, in each of these populations, as no staining was detected under absorption control conditions.

Immunohistochemical demonstration of neuropeptides in the cerebellum has been reported only infrequently. Enkephalin has been demonstrated in climbing fibers in the opossum (King et al., 1986a, b), in mossy fibers in mammals (Schulman et al., 1981; King et al., 1986a), fish, frogs, and pigeon (Schulman et al., 1981), and in Golgi cells in mammals (Sar et al., 1978; Schulman et al., 1981; Williams and Dockray, 1983) and goldfish (Schulman et al., 1981). Cholecystokinin (CCK) is present in mossy fibers and climbing fibers of the opossum (King et al., $1986 \mathrm{c}$, and personal communication). Motilin immunoreactivity has been reported in Purkinje cells in rats and mice (ChanPalay et al., 1981; Nilaver et al., 1982) and monkeys (ChanPalay et al., 1981). Johansson and colleagues (1984) demonstrated somatostatin in Golgi cells, Purkinje cells, and single fibers of rat cerebellar cortex, though Inagaki and coworkers (Inagaki et al., 1982a) were able to detect somatostatin-immunoreactive neurons fibers in rats only in newborn tissues. Korte et al. (1980) demonstrated substance $P$ in mossy fibers in turtle cerebellum. Inagaki and colleagues $(1982 \mathrm{a}, \mathrm{b})$ reported that substance P-immunoreactive fibers were discernible in rat cerebellum only until 2 weeks postnatally.

Each of the CRF-IR fiber populations observed in this study appeared to be distributed nonhomogeneously within the floccular and parafloccular cortex. Nonuniform distribution of other putative neuromediators within cerebellar tissue has also been reported. The peptides enkephalin (Schulman et al., 1981; King et al., 1986a, b), motilin (Chan-Palay et al., 1981; Nilaver et al., 1982), and CCK (King et al., 1986c), the monoamine 5-HT (Takeuchi et al., 1982; Bishop and Ho, 1985; Bishop et al., 1985), GABA (Chan-Palay et al., 1981), and the enzymes AChE and cytochrome oxidase (Hess and Voogd, 1986), all appear subject to degrees of chemically defined organization within the cerebellum. The distribution of CRF within the entire cerebellum of any species has not yet been mapped, and the representation of this peptide within lobules other than the flocculus and paraflocculus is at present unknown. However, a recent analysis of CRF-IR fiber distribution in the cerebellum of the adult opossum has shown that CRF-IR climbing fibers and mossy fibers are present in patterned, nonuniform systems in that species (Cummings et al., 1987). The existence of nonhomogeneous distribution of CRF immunoreactivity in the cerebellum could provide one explanation for the differing observations of previous studies on the existence of this peptide, with results dependent on the region of the cerebellum sampled.

The morphology and uneven distribution of the CRF fiber systems visualized in this study bore similarities to the enkephalin- and CCK-IR systems described by King and coworkers $(1986 \mathrm{a}-\mathrm{c})$ in the opossum. The CRF-, enkephalin-, and CCKIR climbing fiber and mossy fiber populations each include both simple enlarged varicosities reminiscent of boutons en passant and the more complex configurations suggestive of boutons termineux described in Golgi preparations (Ramon y Cajal, 1911; Brodal and Drablos, 1963; Palay and Chan-Palay, 1974), and each appears to display nonuniform distributions. Of special interest is the resemblance of the CRF, enkephalin (King et al., 1986a), and CCK (J. S. King, personal communication) beaded fiber plexuses surrounding the Purkinje cell somata, for these beaded fiber plexuses also bear likeness to norepinephrine(Bloom et al., 1971) and 5-HT- (Bishop et al., 1985) containing fiber plexuses which have been described at the level of the
Purkinje cell somata. Supra- and infraganglionic plexuses at this level of the cerebellar cortex have been described classically as longitudinal extensions of Purkinje cell collaterals (Jakob, 1928; Larsell and Jansen, 1972). However, neither of the monoaminergic systems nor the enkephalin or CCK beaded fiber systems observed by King and colleagues were described as arising from the adjacent Purkinje cell population. In the lobules surveyed in the present study, the flocculus and paraflocculus, fibers within the CRF-IR beaded plexus were not observed arising from Purkinje cell axon collaterals. Thus, the origin of the CRF-IR ganglionic fiber plexus and its relationship to classical cerebellar fiber systems are unknown at this time.

The similarity of CRF-IR fiber populations to enkephalincontaining climbing fibers and to enkephalin- and CCK-containing mossy fiber distributions raises the possibility for coexistence of these peptides within the cerebellum. The comparable location of CRF, norepinephrine, and 5-HT within fibers of the Purkinje cell-associated beaded fiber complex, also suggests the possibility of cocontainment of CRF with monoamines in that system. CRF has been shown to coexist with several other peptides (Roth et al., 1983; Kiss et al., 1984; Sawchenko and Swanson, 1985), including enkephalin (Hökfelt et al., 1983) and CCK (Mezey et al., 1986), within the paraventricular nucleus of the rat hypothalamus. The colocalization of other peptides with both 5-HT and norepinephrine has also been demonstrated (Hökfelt et al., 1978, 1980; Caffe et al., 1985). In addition to the paraventricular nucleus and inferior olive, CRFIR somata have been localized in the locus ceruleus, parabrachial nucleus, nucleus prepositus, nucleus of the solitary tract, parvocellular, gigantocellular, and lateral reticular nuclei, and several nuclei of the raphe system in the rat (Olschowka et al., 1982; Cummings et al., 1983; Schipper et al., 1983; Swanson et al., 1983; Merchenthaler, 1984) and the opossum (Cummings et al., 1987). Each of these brain-stem regions is known to project to the cerebellum (Olson and Fuxe, 1971; Taber-Pierce et al., 1977; Somana and Walberg, 1979; Gould, 1980; Sato et al., 1983a, b; Haines et al., 1984). Populations of enkephalin- (Hökfelt et al., 1977; Williams and Dockray, 1983; King et al., 1986a, b), CCK- (Innis et al., 1979; Loren et al., 1979; Vanderhaeghen et al., 1980), 5-HT-(Steinbusch, 1981; Bishop and Ho, 1985), or norepinephrine- (Dahlstrom and Fuxe, 1964) containing neurons have also been found within one or more of these CRFcontaining regions. It is reasonable, therefore, to hypothesize dual transmitter-containing mossy fiber or other afferent-type projections from such brain-stem locations to the cerebellum.

\section{Distribution of CRF-IR somata within the inferior olive}

The present study has identified CRF-containing cell bodies within all subdivisions of the cat inferior olivary complex, with a primary antiserum directed against rat/human CRF. Additionally, it has revealed that both the density of labeled cells and the intensity of CRF-PAP staining vary within divisions of that complex. These results suggest that regions of the inferior olive in which the number of CRF-IR cells appears to be greater may support denser projections to some cerebellar lobules. The appearance of more intense immunostaining of some CRF-IR somata within the inferior olive may reflect higher levels of synthesis of the peptide within some neuronal populations of that nucleus. It therefore could be conjectured that higher concentrations of CRF might be present not only in cerebellar folia receiving greater numbers of, in this instance, climbing fibers, but also that climbing fibers from subregions of the inferior olive 
with higher levels of CRF synthesis may contain higher levels of this peptide.

Several explanations may now be suggested for the varied findings of previous studies on the existence of CRF in the cerebellum. As has been discussed, CRF antisera have been shown to identify overlapping, but on occasion, different cell and fiber populations (Skofitsch and Jacobowitz, 1985). Thus, variation in the specificity of CRF antisera utilized could provide one cause for differences in reported observations.

Additionally, however, CRF-like enkephalin (King et al., 1986), 5-HT (Bishop et al., 1985), and motilin (Chan-Palay et al., 1981)-appears to have an uneven distribution within the cerebellar cortex. Therefore, depending on the cerebellar region sampled in radioimmunoassay studies or in other CRF immunohistochemical studies, other potential causes of disparate results could include the nonhomogeneous distribution of CRFcontaining fibers, quantitative variation in levels of the peptide within afferent projection fibers, and variation in the density of afferent fiber projections from precerebellar nuclei to different regions of the cerebellar cortex.

Historically, discrepancies between data collected from radioimmunoassay and immunocytochemical studies have not been uncommon. The existence of heterogeneous forms of peptides as antigenic determinants in immunohistochemical procedures, and the potential that exists for alteration in peptide structure by fixation procedures, provide additional reasons for variations in findings (see reviews by Van Leeuwen, 1982; Elde, 1983; Pool et al., 1983).

\section{Retrograde tracing study}

The results of the retrograde tracing study indicate that populations of CRF-IR somata within the inferior olive project to the flocculus and paraflocculus as climbing fibers. There were, however, CRF-containing perikarya in the inferior olive to which there was no retrograde dye transport. Because the inferior olivary complex projects climbing fibers to all regions of the cerebellar cortex, the potential exists for a more widespread CRFIR climbing fiber distribution than was observed in this study. Furthermore, FB did transport from the flocculus and paraflocculus to extra-olivary brain-stem precerebellar cell groups wherein CRF perikaryal immunostaining was also present. Although this study did not analyze possible colocalization of CRF and the retrogradely transported dye in these extra-olivary regions, these results suggest that potential origins for CRF-containing mossy fiber and ganglionic beaded fiber afferents do exist.

Mapping of the overall distribution of CRF-IR fibers within the cerebellum may delineate a pattern of organization for the diverse population of CRF profiles revealed in this study. Detailed ultrastructural analysis of the CRF profiles and their relationships to the other elements of cerebellar cytoarchitecture may provide insight into the role of CRF in cerebellar circuitry. The demonstration of ovine CRF binding sites throughout the cerebellum (Wynn et al., 1984; De Souza et al., 1986) suggests a possible role for a CRF-likc substance as a neurotransmitter or neuromodulator within this region. However, the functional significance of CRF within the cerebellum remains to be explored.

Finally, findings of this study suggest regional variation in CRF distribution in the cerebellum and support a notion of chemical coding in cerebellar architecture. The demonstration of discrete compartmentalization of putative neuromediators such as $\mathrm{CRF}$ within the cerebellum may well provide foundation for future studies on the organization of chemically coded circuitry within this region of the nervous system.

\section{References}

Bishop, G., and R. Ho (1985) The distribution and origin of serotonin immunoreactivity in the rat cerebellum. Brain Res. 331: 195-207.

Bishop, G., R. Ho, and J. S. King (1985) Localization of serotonin immunoreactivity in the opossum cerebellum. J. Comp. Neurol. 235: 301-321.

Bloom, F., B. Hoffer, and G. Siggins (1971) Studies on norepinephrinecontaining afferents to Purkinje cells of rat cerebellum. I. Localization of the fibers and their synapses. Brain Res. 25: 501-521.

Bloom, F., E. Battenberg, J. Rivier, and W. Vale (1982) Corticotropin releasing factor (CRF): Immunoreactive neurones and fibers in rat hypothalamus. Regulat. Peptides 4: 43-48.

Brodal, A., and P. Drablos (1963) Two types of mossy fiber terminals in the cerebellum and their regional distribution. J. Comp. Neurol. 121: 173-187.

Caffe, A., F. van Leeuwen, R. Buijs, G. de Vries, and M. Geffard (1985) Coexistence of vasopressin, neurophysin, and noradrenaline immunoreactivity in medium-sized cells of the locus coeruleus and subcoeruleus in the rat. Brain Res. 338: 160-164.

Chan-Palay, V., G. Nilaver, S. Palay, M. Beinfeld, E. Zimmerman, J. $\mathrm{Wu}$, and T. O'Donohue (1981) Chemical heterogeneity in cerebellar Purkinje cells: Existence and coexistence of glutamic-acid decarboxylase-like and motilin-like immunoreactivities. Proc. Natl. Acad. Sci. USA 78: 7787-7791.

Coons, A. H. (1958) Fluorescent antibody methods. In General $\mathrm{Cy}$ tochemical Methods, J. Danielli, ed., Academic, New York.

Cote, J., G. Lefevre, F. Labrie, and N. Barden (1983) Distribution of corticotropin-releasing factor in ovine brain determined by radioimmunoassay. Regulat. Peptides 5: 189-195.

Cummings, S., R. Elde, J. Ells, and A. Lindall (1983) Corticotropinreleasing factor immunoreactivity is widely distributed within the central nervous system of the rat: An immunohistochemical study. J. Neurosci. 3: 1355-1368.

Cummings, S., R. Elde, and B. Sharp (1985) CRF-immunoreactive neurons within the inferior olive project to the flocculus and dorsal and ventral paraflocculus. Proc. Soc. Neurosci. 11: 683.

Cummings, S., G. Bishop, and J. S. King (1987) Corticotropin releasing factor (CRF) in cerebellar cortex and precerebellar nuclei of the opossum. Anat. Rec. 218: 29A.

Dahlstrom, A., and K. Fuxe (1964) Evidence for the existence of monoamine-containing neurons in the central nervous system. I. Demonstration of monoamines in the cell bodies of brain stem neurons. Acta. Physiol. Scand. Suppl. 62, 232: 1-55.

De Souza, E., T. Insel, M. Perrin, J. Rivier, W. Vale, and M. Kuhar (1986) Corticotropin-releasing factor receptors are widely distributed within the rat central nervous system: An autoradiographic study. J. Neurosci. 5: 3189-3203.

Elde, R. (1983) Immunocytochemistry. In Brain Peptides, D. Krieger, M. Brownstein, and J. Martin, eds., pp. 485-494, Wiley, New York. Fischman, A., and R. Moldow (1982) Extrahypothalamic distribution of CRF-like immunoreactivity in the rat brain. Peptides $1: 149-153$.

Gould, B. B. (1980) Organization of afferents from the brainstem nuclei to the cerebellar cortex in the cat. Adv. Anat. Embryol. Cell Biol. 62: 1-90.

Haines, D., E. Dietrichs, and T. Sowa (1984) Hypothalamo-cerebellar and cerebello-hypothalamic pathways: A review and hypothesis concerning cerebellar circuits which may influence autonomic centers and affective behavior. Brain Behav. Evol. 24: 198-220.

Hess, D., and J. Voogd (1986) Chemoarchitectonic zonation of the monkey cerebellum. Brain Res. 369: 383-387.

Hökfelt, T., and K. Fuxe (1969) Cerebellar monoamine nerve terminals, a new type of afferent fibers to the cortex cerebelli. Exp. Brain Res. 9: 63-72.

Hökfelt, T., R. Elde, O. Johansson, L. Tcrenius, and L. Stcin (1977) The distribution of enkephalin-immunoreactive cell bodies in rat central nervous system. Neurosci. Lett. 5: 25-31.

Hökfelt, T., A. Ljungdahl, H. Steinbusch, A. Verhofstad, G. Nilsson, E. Brodin, B. Pernow, and M. Goldstein (1978) Immunohistochemical evidence of substance P-like immunoreactivity in some 5-hydroxytryptamine-containing neurons in the rat central nervous system. Neuroscience 3: 517-538. 
Hökfelt, T., J. Lundberg, M. Schultzberg, O. Johansson, A. Ljungdahl, and J. Rehfeld (1980) Coexistence of peptides and putative transmitters in neurons. In Neural Peptides and Neuronal Communication, E. Costa and M. Trabucci, eds., pp. 1-23, Raven, New York.

Hökfelt, T., I. Fahrenkrug, K. Tatemoto, V. Mutt, S. Werner, A. Hultings, L. Terenius, and $\mathrm{K}$. Chang (1983) The PHI (PHI-27) corticotropin-releasing factor/enkephalin immunoreactive hypothalamic neuron: Possible morphological basis for integrated control of prolactin, corticotrophin, and growth hormone secretion. Proc. Natl. Acad. Sci. USA 80: 895-898.

Inagaki, S., S. Shiosaka, K. Takatsuki, H. Iida, M. Sakanaka, E. Senba, Y. Hara, T. Matsuzaki, Y. Kawai, and M. Tohyama (1982a) Ontogeny of somatostatin-containing neuron system of the rat cerebellum including its fiber connections: An experimental and immunohistochemical analysis. Dev. Brain Res. 3: 509-527.

Inagaki, S., M. Sakanaka, S. Shiosaka, E. Senba, H. Takagi, K. Takatsuke, Y. Kawai, T. Matsuzaki, H. Iida, H. Hara, and M. Tohyama (1982b) Experimental and immunohistochemical studies on the cerebellar substance $\mathbf{P}$ of the rat: Localization, postnatal ontogeny and ways of entry to the cerebellum. Neuroscience 7: 639-645.

Innis, R., F. Correa, G. Uhl, B. Schneider, and S. Snyder (1979) Cholecystokinin octapeptide-like immunoreactivity: Histochemical localization in rat brain. Proc. Natl. Acad. Sci. USA 76: 521-525.

Jakob, A. (1928) Das kleinhirn. In Handbuch der mikroskopischen Anatomie des Menschen, Vol. 4, W. von Mollendrof, ed., Springer, Berlin.

Johansson, O., and T. Hökfelt (1980) Thyrotropin releasing hormone, somatostatin and enkephalin: Distribution studies using immunohistochemical techniques. J. Histochem. Cytochem. 28: 364-366.

Johansson, O., T. Hökfelt, and R. Elde (1984) Immunohistochemical distribution of somatostatin-like immunoreactivity in the central nervous system of the adult rat. Neuroscience $13: 265-269$.

King, J. S., R. Ho, and G. Bishop (1986a) The origin and distribution of enkephalin-like immunoreactivity in the opossum's cerebellum. In New Concepts in Cerebellar Neurobiology, J. King, ed., Alan Liss, New York.

King, J. S., R. Ho, and G. Bishop (1986b) Anatomical evidence for enkephalin immunoreactive climbing fibers in the opossum's cerebellar cortex. J. Neurocytol. 15: 545-559.

King, J. S., R. Ho, and G. Bishop (1986c) Cholecystokinin-like immunoreactivity in the cerebellum of the opossum. Proc. Soc. N.S. 12: 461

Kiss, J., E. Mezey, and L. Skirboll (1984) Corticotropin-releasing factor-immunoreactive neurons of the paraventricular nucleus become vasopressin positive after adrenalectomy. Proc. Natl. Acad. Sci. USA 81: $1854-1858$

Korte, G., E. Reiner, and H. Karten (1980) Substance P-like immunoreactivity in cerebellar mossy fibers and terminals in the red-eared turtle Chrysemys scripta elegans. Neuroscience 5: 903-914.

Larsell, $O$. (1972) The human cerebellum, cerebellar connections and cerebellar cortex. In The Comparative Anatomy and Histology of the Cerebellum, J. Jansen, ed., pp. 203-208, University of Minnesota Press, Minncapolis.

Larsson, L.-I. (1981) A novel immunocytochemical model system for specificity and sensitivity screening of antisera against multiple antigens. J. Histochem. Cytochem. 29: 408-410.

Loren, I., J. Alumets, R. Hakanson, and F. Sundler (1979) Distribution of gastrin and CCK-like peptides in rat brain. An immunocytochemical study. Histochemistry 59: 249-257.

Merchenthaler, I. (1984) Corticotropin releasing factor (CRF)-like immunoreactivity in the rat central nervous system. Extrahypothalamic distribution. Peptides 5: 53-69.

Mezey, E., T. Reisine, L. Skirboll, M. Beinfeld, and J. Kiss (1986) role of cholecystokinin in corticotropin release: Coexistence with vasopressin and corticotropin-releasing factor in cells of the rat hypothalamic paraventricular nucleus. Proc. Natl. Acad. Sci. USA 83: 3510 3512.

Nilaver, G., R. Defendini, E. Zimmerman, M. Beinfeld, and T. O'Donohue (1982) Motilin in the Purkinje cells of the cerebellum. Nature 295: 597-598.

Olschowka, J., T. O'Donohue, G. Mueller, and D. Jacobowitz (1982) The distribution of corticotropin releasing factor-like immunoreactive neurons in the rat brain. Peptides 3: 995-1015.

Olson, L., and K. Fuxe (1971) On the projections from the locus coeruleus noradrenaline neurons: The cerebellar innervation. Brain Res. 28: 165-171.

Onstott, D., and R. Elde (1984) Immunohistochemical localization of urotensin I/ corticotropin-releasing factor immunoreactivity in neurosecretory neurons in the caudal spinal cord of fish. Neuroendocrinology 39: 503-509.

Palay, S., and V. Chan-Palay (1974) Cerebellar Cortex. Cytology and Organization, Springer-Verlag. New York

Palkovits, M., M. Brownstein, and W. Vale (1985) Distribution of corticotropin-releasing factor in rat brain. Fed. Proc. 44: 215-219.

Paull, W., J. Scholer, A. Arimura, C. Meyers, J. Chang, D. Chang, and M. Shimizu (1982) Immunocytochemical localization of CRF in the ovine hypothalamus. Peptides $1: 183-191$.

Platt, J., and A. Michael (1983) Retardation of fading and enhancement of intensity of immunofluorescence by p-phenylenediamine. J. Histochem. Cytochem. 31: 840-842.

Pool, C., R. Buijs, D. Swaab, G. Boer, and F. van Leeuwen (1983) On the way to a specific immunocytochemical localization. In Immunocytochemistry, C. Cuello, ed., pp. 1-46, Wiley, New York.

Powers, R., E. De Souza, L. Walker, W. Vallet, D. Price, and W. S. Young III (1986) Corticotropin-releasing factor as a transmitter of inferior olivary neurons. Proc. Soc. Neurosci. 12: 568

Ramon y Cajal, S. (1911) Histologie du Systeme Nerveux de l'Homme et des Vertebres, Vol. 2, Maloine, Paris.

Roth, K., E. Weber, and J. Barchas (1983) Immunoreactive dynorphin-(1-8) and corticotropin-releasing factor in subpopulation of hypothalamic neurons. Science 219: 189-191.

Sano, Y., and Y. Takeuchi (1984) In The Cerebellum and Neural Control, M. Ito, ed., p. 278, Raven, New York.

Sar, M., W. Stumpf, R. Miller, K.-J. Chang, and P. Cuatrecasas (1978) Immunohistochemical localization of enkephalin in rat brain and spinal cord. J. Comp. Neurol. 182: 17-38.

Sato, Y., T. Kawasaki, and K. Ikarashi (1983a) Afferent projections from the brainstem to the three floccular zones in cats. I. Climbing fiber projections. Brain Res. 272: 27-36.

Sato, Y., T. Kawasaki, and K. Ikarashi (1983b) Afferent projections from the brainstem to the three floccular zones in cats. II. Mossy fiber projections. Brain Res. 272: 37-48.

Sawchenko, P., and L. Swanson (1985) Localization, co-localization and plasticity of CRF-immunoreactivity in the rat brain. Fed. Proc. 44: 221-227.

Sawchenko, P., L. Swanson, J. Rivier, and W. Vale (1985) The distribution of growth-hormone-releasing factor (GRF) immunoreactivity in the central nervous system of the rat: An immunohistochemical study using antisera directed against rat hypothalamic GRF. J. Comp. Neurol. 237: 100-115.

Schipper, J., H. Steinbusch, I. Vermes, and F. Tilders (1983) Mapping of CRF-immunoreactive nerve fibers in the medulla oblongata and spinal cord of the rat. Brain Res. 267: 145-150.

Schmued, I., I. Swanson, and P. Sawchenko (1982) Some fluorescent counterstains for neuroanatomical studies. J. Histochem. Cytochem. 30: $123-128$

Schulman, J., T. Finger, N. Brecha, and H. Karten (1981) Enkephalin immunoreactivity in golgi cells and mossy fibres of mammalian, avian, amphibian and teleost cerebellum. Neuroscience 6: 2407-2416.

Skotitsch, G., and D. Jacobowitz (1985) Distribution of corticotropin releasing factor-like immunoreactivity in the rat brain by immunohistochemistry and radioimmunoassay: Comparison and characterization of ovine and rat/human CRF antisera. Peptides 6: 319-336.

Somana, R., and F. Walberg (1979) Cerebellar afferents from the nucleus of the solitary tract. Neuroscience 11:41-47.

Spiess, J, R. Rivier, C. Rivier, and W. Vale (1981) Determination of the primary structure of corticotropin releasing factor from ovine hypothalamus. Proc. Natl. Acad. Sci. USA 78: 6517-6521.

Steinbusch, H. (1981) Distribution of serotonin-immunoreactivity in the central nervous system of the rat-cell bodies and terminals. Neuroscience 6: 557-618.

Stephanini, M., C. De Martino, and L. Zamboni (1967) Fixation of ejaculated spermatozoa for electron microscopy. Nature 216: 173174.

Sternberger, L. A. (1979) Immunocytochemistry, Wiley, New York.

Swanson, L., P. Sawchenko, J. Rivier, and W. Vale (1983) Organization of ovine corticotropin-releasing factor immunoreactive cells and fibers in the rat brain: An immunohistochemical study. Neuroendocrinology $36: 165-186$.

Taber-Pierce, E., G. Hoddevik, and F. Walberg (1977) The cerebellar projection from the raphe nuclei in the cat as studied with the method of retrograde transport of horseradish peroxidase. Anat. Embryol. 152: 73-87. 
Takeuchi, Y., H. Kimura, and Y. Sano (1982) Immunohistochemical demonstration of serotonin-containing nerve fibers in the cerebellum. Cell Tissue Res. 226: 1-12.

Vale, W., J. Spiess, C. Rivier, and J. Rivier (1981) Characterization of a 41 residue ovine hypothalamic peptide that stimulates the secretion of corticotropin and beta-endorphin. Science 213: 1394-1397.

Vanderhaeghen, J., F. Lotstra, J. Demey, and C. Giles (1980) Immunohistochemical localization of cholecystokinin- and gastrin-like peptides in the brain and hypophysis of the rat. Proc. Natl. Acad. Sci. USA 77: 1190-1194.

Van Leeuwen, F. (1982) Specific immunocytochemical localization of neuropeptides: A utopian goal? In Techniques in Immunocytochemistry, Vol. 1, G. Bullock and P. Petusz, eds., pp. 283-299, Academic, New York.
Williams, R., and G. Dockray (1983) Distribution of enkephalinrelated peptides in rat brain: Immunohistochemical studies using antisera to met-enkephalin and met-enkephalin $\mathrm{Arg}^{6} \mathrm{Phe}^{7}$. Neuroscience 9: $563-586$.

Witkin, J., C. Paden, and A.-J. Silverman (1982) The leuteinizing hormone-releasing hormone (LHRH) systems in the rat brain. Neuroendocrinology 35: 429-438.

Wynn, P., R. Hauger, M. Holmes, M. Millan, K. Catt, and G. Aguilera (1984) Brain and pituitary receptors for corticotropin releasing factor: Localization and differential regulation after adrenalectomy. Peptides 5: $1077-1084$ 